\title{
TRANSMISI, EKSPRESI, DAN DISTRIBUSI GEN HORMON PERTUMBUHAN IKAN PATIN SIAM PADA IKAN LELE AFRIKA (Clarias gariepinus) TRANSGENIK F-2
}

\author{
Huria Marnis, Bambang Iswanto, Rommy Suprapto, Imron, dan \\ Raden Roro Sri Pudji Sinarni Dewi \\ Balai Penelitian Pemuliaan Ikan \\ Jl. Raya 2 Sukamandi, Subang 41263 \\ E-mail: huria_marnis@yahoo.com
}

(Naskah diterima: 2 April 2014; Disetujui publikasi: 10 Juli 2014)

\begin{abstract}
ABSTRAK
Salah satu keberhasilan pembentukan ikan transgenik ditandai dengan kemampuan dari individu transgenik tersebut untuk mewariskan transgen pada keturunannya. Penelitian ini bertujuan untuk mengevaluasi transmisi dan ekspresi transgen ( $P h C h)$ dari generasi F-1 ke F-2 serta mengetahui distribusi transgen pada berbagai organ. Deteksi transgen dilakukan pada larva, benih, dan berbagai organ ikan lele generasi F-2 (pituitari, otak, timus, jantung, limfa, hati, ginjal, lambung, usus, gonad, otot, kulit insang, dan sirip ekor) menggunakan metode PCR. Ekspresi transgen pada larva dan organ ikan lele transgenik F-2 dideteksi menggunakan metode reverse transcriptasepolymerase chain reaction (RT-PCR). Level ekspresi pada organ dianalisis menggunakan metode qPCR, gen $\beta$-aktin digunakan sebagai kontrol internal. Hasil penelitian ini menunjukkan bahwa sebanyak 65 ekor induk betina transgenik F-1 positif membawa transgen di sirip ekor, hanya 18 ekor $(27,69 \%)$ induk betina yang positif membawa transgen di telur. Sedangkan pada induk jantan hanya 19 ekor $(46,34 \%)$ yang positif membawa transgen di sperma, dari 41 ekor yang positif membawa transgen di sirip. Transgen dapat terdeteksi pada larva dan sirip ekor ikan lele transgenik F-2 dengan persentase transmisinya adalah $8,11 \%-50 \%$ dengan rata-rata transmisi transgen sebesar $18,85 \%$. Deteksi dan distribusi transgen ditemukan pada larva dan organ pituitari, hati, ginjal, gonad, otot, otak, timus, jantung, limfa, lambung, usus, insang, dan sirip ekor, tetapi transgen tidak ditemukan pada kulit ikan. Level ekspresi transgen tertinggi ditemukan pada hati sebesar $7,3 \pm 2,2 \mathrm{pg} / \mu \mathrm{g}$ cDNA $-9,2 \pm 2,7 \mathrm{pg} / \mu \mathrm{g}$ cDNA; sedangkan ekspresi terendah ditemukan pada ginjal berkisar $0,19 \pm 0,01 \mathrm{pg} / \mu \mathrm{g}$ cDNA - 0,2 $\pm 0,03$ $\mathrm{pg} / \mu \mathrm{g}$ cDNA; dan insang sebesar $0,2 \pm 0,01 \mathrm{pg} / \mu \mathrm{g}$ cDNA.
\end{abstract}

KATA KUNCl: Clarias gariepinus, transmisi, ekspresi, transgenik, hormon pertumbuhan

ABSTRACT: Transmission, expression and growth hormone gene distribution of striped catfish in African catfish (Clarias gariepinus) transgenic F-2. By: Huria Marnis, Bambang Iswanto, Rommy Suprapto, Imron, dan Raden Roro Sri Pudji Sinarni Dewi

One of the successful production of transgenic fish was characterized by the ability of the transgenic individuals to pass the transgene in the offspring. This study aimed to evaluate the transmission and expression of the transgene (PhGh) from F-1 to F-2 generation as well as to detect the distribution of the transgene in various organs. Transgene detection performed on larvae, seeds, and various organs of African catfish 
F-2 generation (pituitary, brain, thymus, heart, spleen, liver, kidneys, stomach, intestines, gonads, muscle, skin, gills, and caudal fin) using the PCR method. Transgene expression in larvae and organs was detected using reverse transcriptase-polymerase chain reaction (RT-PCR). Expression levels in the organs was analyzed using $9 P C R$ ), $\beta$ actin gene used as internal controls. The results showed that transgene could be detected in larvae and caudal fin of catfish transgenic F-2 with transmission percentage was $8.11 \%-50 \%$ with an average of transgene transmission was $18.85 \%$. Detection and distribution of the transgene were found in larvae and pituitary organs, liver, kidneys, gonads, muscle, brain, thymus, heart, spleen, stomach, intestine, gills, and caudal fin, but no detectable transgene in skin fish. The highest level of transgene expression was found in the liver range from $7.3 \pm 2.2 \mathrm{pg} / \mathrm{mg} \mathrm{CDNA}-9.2 \pm 2.7 \mathrm{pg} / \mathrm{mg}$ cDNA, while the lowest expression was found in kidney ranged from $0.19 \pm 0.01 \mathrm{pg} / \mathrm{mg}$ cDNA $-0.2 \pm 0.03 \mathrm{pg} / \mathrm{mg} \mathrm{cDNA}$ and gills of $0.2 \pm 0.01 \mathrm{pg} / \mathrm{mg}$ cDNA.

\section{KEYSWORDS: Clarias gariepinus, transmission, expression, transgenic, growth hormone}

\section{PENDAHULUAN}

Menurut proyeksi, pada tahun 2030 populasi dunia akan melebihi delapan miliar orang, dan diharapkan perikanan akuakultur dapat memenuhi tingginya permintaan manusia akan protein hewani salah satunya ikan. Penggunaan teknologi transgenik untuk menghasilkan strain ikan unggul dengan karakter tertentu menjadi salah satu strategi untuk memenuhi permintaan tersebut (Cressey, 2009). Transgenesis telah digunakan dalam bidang akuakultur sejak pertengahan tahun 1980-an (Zhu et al., 1985). Saat ini, studi transfer gen telah dilakukan pada lebih dari 35 spesies ikan, termasuk spesies komersial penting seperti: ikan mas, nila, channel catfish, rainbow trout, dan salmon (Hu \& Zhu, 2010). Adapun rekayasa genetika yang diaplikasikan antara lain adalah untuk peningkatan pertumbuhan (Devlin et al., 1994; Du et al., 1992; Hallerman et al., 2007; Martinez et al., 1996; Nam et al., 2001; Rahman et al., 1998; Zhu et al., 1985). Perbaikan metabolisme (Krasnov et al., 1999), tahan penyakit (Cole et al., 2000; Douglas et al., 2001; Fletcher et al., 2011; Mao et al., 2004; Zhong et al., 2002) dan tahan terhadap lingkungan yang ekstrim seperti tahan terhadap suhu dingin dan hipoxia (Guan et al., 2011 ; Hew et al., 1999; Shears et al., 1991; Wang et al., 1995). Penelitian transgenik dengan mentransfer gen pengkode hormon pertumbuhan pada ikan budidaya telah berkembang dengan baik, oleh karena itu, diharapkan pertumbuhannya lebih cepat sehingga dapat dikomersialkan untuk produk pangan.

Pada pembentukan ikan transgenik, transgen harus dapat terintegrasi pada germline dan ditransmisikan pada generasi berikutnya. Beberapa penelitian tentang mekanisme integrasi transgen pada genom inang dan transmisi transgen pada generasi berikutnya telah berhasil dilakukan pada ikan mas transgenik (Cyprinus carpio) (Wang et al., 2001), salmon Atlantik (Salmo salar) (Devlin et al., 2004), Coho salmon (Oncorhynchus kisutch) (Fletcher et al., 2011 ), ikan Misgurrus mizolepis (Nam et al., 2001) dan nila (Oreochromis nilotius) (Martínez et al., 1999; Rahman et al., 2001). Selain transgen dapat ditransmisikan, transgen juga sebaiknya dapat diekspresikan pada jaringan dan organ generasi berikutnya (Farlora et al., 2009; Caelers et al., 2005).

Pada penelitian sebelumnya telah dihasilkan ikan lele transgenik F-1 yang mempunyai pertumbuhan dua kali lipat dibanding kontrol (non-transgenik). Ikan lele F-1 yang dihasilkan diharapkan dapat menurunkan karakteristik pertumbuhan cepat pada generasi kedua (F-2). Ikan transgenik F-1 yang dihasilkan digunakan untuk memproduksi $\mathrm{F}-2$ dengan cara mengawinkan sesama induk transgenik F-1. Penelitian ini bertujuan untuk mengetahui transmisi, ekspresi dan distribusi transgen $(\mathrm{PhGH})$ pada populasi ikan transgenik F-2.

\section{BAHAN DAN METODE}

\section{Ikan Sampel}

Ikan uji yang digunakan pada penelitian ini adalah ikan lele Afrika transgenik F-2. Enam pasang ikan lele transgenik F-1 disilangkan secara buatan sehingga menghasilkan keturunan ikan transgenik generasi ke- 
dua (F-2), yang membawa konstruksi plasmid pCcBA-PhGH (Dewi, 2010).

\section{Deteksi Gen PhGH pada Ikan Lele F-2}

\section{Ekstraksi DNA}

Deteksi gen PhGH dilakukan pada 50 ekor ikan lele transgenik jantan F-1 dan 175 ekor ikan lele transgenik betina. Ekstraksi DNA dilakukan pada gonad (sperma dan telur), larva yang berumur satu hari dan benih ikan lele F-2 yang berumur 1,5 bulan. Deteksi gen $\mathrm{PhGH}$ juga dilakukan pada organ (pituitari, otak, timus, jantung, limfa, hati, ginjal, lambung, usus, gonad, otot, kulit, dan insang) dari tiga individu ikan lele transgenik F-2 yang berumur 1,5 bulan. DNA genom ikan lele diekstraksi dari sepuluh ekor larva yang digabung dari enam pasang induk transgenik, sedangkan ekstraksi DNA pada benih dilakukan per individu sebanyak 122 ekor. Ekstraksi DNA menggunakan kit GeneJet Genomic DNA Purification (Thermo Scientific) sesuai dengan petunjuk penggunaan. Tingkat kemurnian dan kuantitas RNA diukur menggunakan qubit ${ }^{\circledR} 2.0$ fluorometri (Invitrogen).

\section{Amplifikasi Polymerase Chain Reaction (PCR)}

Deteksi transgen dilakukan pada DNA genom hasil ekstraksi dengan PCR menggunakan kit faststart PCR master (Roche, Germany) dan diamplifikasi dengan PCR mycycler (Biorad). Komposisi bahan yang digunakan untuk proses PCR adalah $10 \mu \mathrm{L}$ master kit PCR, $1,5 \mu \mathrm{L}$ primer (10 pmol/ $\mu \mathrm{L}), 2 \mu \mathrm{L}$ DNA genom dan ditambahkan water free RNAse hingga mencapai total volume $25 \mu \mathrm{L}$. Primer yang digunakan adalah FphGH1 (5'- TAG AGT GTT GGT GGT GCT CTC TGT -3') dan RphGH2 (5'CGA TAA GCA CGC CGA TGC CCA TIT-3') (Dewi et al., 2013). Ukuran fragmen gen $P h G H$ adalah 392 bp. Proses PCR dilakukan dengan denaturasi pada suhu $94^{\circ} \mathrm{C}$ selama 30 detik, penempelan primer pada suhu $55^{\circ} \mathrm{C}$ selama 30 detik dan pemanjangan pada suhu $72^{\circ} \mathrm{C}$ selama satu menit, sebanyak 35 siklus. Hasil PCR dipisahkan dengan menggunakan elektroforesis pada gel agarose (vivantis) 2,0\% dalam larutan TBE 1 x selama 60 menit pada tegangan 70 volt. Sebanyak $3 \mu \mathrm{L}$ volume amplikon dicampur dengan loading dye 1,0 $\mu \mathrm{L}$. Gel di-staining dengan gelred (biotium) dengan konsentrasi $1 \mu \mathrm{g} / \mathrm{mL}$. Hasil elektroforesis DNA divisualisasi menggunakan UV transluminator.

\section{Analisis Ekspresi Gen PhGH pada Ikan Lele F-2}

\section{Ekstraksi RNA dan sintesis cDNA}

Analisis ekspresi dilakukan pada larva yang berumur satu hari dan organ pituitari, otak, timus, jantung, limfa, hati, ginjal, lambung, usus, gonad, mata, kulit, insang, dan sirip ekor dari tiga individu ikan lele transgenik yang berumur 1,5 bulan. Total RNA diekstraksi dari sepuluh ekor larva F-2 yang digabung dari enam pasang induk transgenik dan organ ikan transgenik F-2 menggunakan kit Tri Reagent (Molecular Research Center, Inc., Cincinnati, $\mathrm{OH}$, USA). Tingkat kemurnian dan kuantitas RNA diukur menggunakan qubit ${ }^{\circledR} 2.0$ fluorometri (Invitrogen). RNA hasil ekstraksi disintesis menjadi cDNA menggunakan kit Ready-To-Go ${ }^{\mathrm{TM}}$ RT-PCR Beads (GE Healthcare).

\section{Ekspresi gen PhGh pada larva menggu- nakan Reverse Transcriptase-Polymerase Chain Reaction (RT-PCR)}

Reverse transcriptase-polymerase chain reaction (RT-PCR) mengunakan alat thermal cycler mycycler (Biorad) yang diprogram dengan 25 siklus. Sebanyak $2 \mu \mathrm{L}$ cDNA digunakan sebagai templet untuk PCR dan $1 \mu \mathrm{L}$ primer FphGH1 (5'- TAG AGT GTT GGT GGT GCT CTC TGT -3') and RphGH2 (5'- CGA TAA GCA CGC CGA TGC CCA TTT-3'). Proses PCR eksogen dilakukan dengan denaturasi pada suhu $94^{\circ} \mathrm{C}$ selama 30 detik, penempelan primer pada suhu $55^{\circ} \mathrm{C}$ selama 30 detik dan pemanjangan pada suhu $72^{\circ} \mathrm{C}$ selama satu menit, dengan ukuran fragmen gen $\mathrm{GH}$ eksogen adalah 392 bp. Gene $\beta$-aktin digunakan sebagai kontrol internal, dengan primer bact- $F$ (5'-TAT GAA GGT TAT GCT CTG CCC-3') dan bact-R (5'-CAT ACC CAG GAA AGA TGG CTG-3') (Dewi et al., 2013). Panjang fragmen $\beta$-aktin ikan lele yang diapit oleh kedua primer tersebut sekitar 300 bp. Proses PCR $\beta$-aktin dilakukan dengan denaturasi pada suhu $94^{\circ} \mathrm{C}$ selama 30 detik, penempelan primer pada suhu $48^{\circ} \mathrm{C}$ selama 30 detik dan pemanjangan pada suhu $72^{\circ} \mathrm{C}$ selama satu menit, sebanyak 25 siklus. Amplikon dipisahkan menggunakan gel agarose $2,0 \%$.

Level ekspresi transgen pada berbagai organ menggunakan Quantitative RealTime PCR (qPCR)

Level ekspresi transgen pada organ pituitari, otak, timus, jantung, limfa, hati, ginjal, 
lambung, usus, gonad, otot, kulit, insang, dan sirip ekor dianalisis secara absolut kuantitatif menggunakan metode real-time PCR. Kuantitas DNA dihitung dari kurva standar yang dibuat dengan serial pengenceran CDNA, dengan rancangan serial pengenceran $10^{-11}$, $10^{-12}, 10^{-13}, 10^{-14}, 10^{-15}, 10^{-16}, 10^{-17}$. Deteksi transgen dianalisis dengan alat Rotor Gene (Qiagen) menggunakan sebanyak 12,5 $\mu \mathrm{L}$ per sampel kit Rotor-Gene SYBR Green (Qiagen).

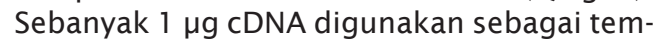
plet, $1 \mu \mathrm{M}$ primer FphGH1 (5'- TAG AGT GTT GGT GGT GCT CTC TGT -3') dan RphGH2 (5'CGA TAA GCA CGC CGA TGC CCA TTT-3') dengan tiga kali ulangan. Proses amplifikasi gen PhGh diawali dengan hold pada suhu $95^{\circ} \mathrm{C}$ selama lima menit, denaturasi pada suhu $95^{\circ} \mathrm{C}$ selama lima detik, amplifikasi pada $55^{\circ} \mathrm{C}$ selama satu menit sebanyak 40 siklus. Gen $\beta$ aktin dengan primer bact-F (5'-TAT GAA GGT TAT GCT CTG CCC-3') dan bact-R (5'-CAT ACC CAG GAA AGA TGG CTG-3') dengan tiga kali ulangan, digunakan sebagai kontrol internal. Proses PCR $\beta$-aktin dilakukan dengan hold pada suhu $95^{\circ} \mathrm{C}$ selama lima menit, denaturasi pada suhu $95^{\circ} \mathrm{C}$ selama lima detik, amplifikasi pada $55^{\circ} \mathrm{C}$ selama satu menit sebanyak 40 siklus.

\section{HASIL DAN BAHASAN}

\section{Deteksi Gen PhGH pada Gonad (Sel Te- lur dan Sperma) Ikan Lele Transgenik F-1}

Sebanyak 65 ekor induk betina transgenik F-1 positif membawa transgen di sirip ekor, hanya 18 ekor $(27,69 \%)$ induk betina yang positif membawa transgen di telur. Sedangkan pada induk jantan hanya 19 ekor $(46,34 \%)$ yang positif membawa transgen di sperma, dari 41 ekor yang positif membawa transgen di sirip (Gambar 1 A, 1B, dan Tabel 1).

Induk ikan lele F-1 positif transgen pada gonad akan digunakan untuk membentuk ikan lele transgenik populasi F-2, karena induk ikan lele yang membawa transgen pada gonad sangat memungkinkan dapat mentransmisikan transgen pada generasi F-2. Chen et al. (1993); Lu et al. (2002) dan Sarmasik (2003), melaporkan bahwa induk yang membawa transgen pada gonad dapat digunakan untuk membentuk generasi berikutnya dan mampu mentransmisikan transgen pada keturunannya.

\section{Deteksi Gen PhGH pada Larva dan Sirip Ekor Ikan Lele Generasi F-2}

Deteksi gen PhGH dilakukan pada larva ikan lele transgenik populasi $\mathrm{F}-2$ dari enam pasang induk transgenik F-1. Gen $\mathrm{PhGH}$ terdeteksi pada semua kelompok larva yang dihasilkan dari enam pasang induk F-1 yang digunakan (Gambar 2). Ini mengindikasikan bahwa semua induk $\mathrm{F}-1$ yang digunakan untuk membentuk ikan transgenik F-2 dapat mentransmisikan transgen PhGH pada keturunannya (Tabel 2). Hasil penelitian ini juga sama dengan yang dilaporkan oleh Liang et al. (2000); Hsio et al. (2001), bahwa rata-rata semua induk ikan transgenik F-1 dapat mentransmisikan transgen pada generasi kedua.
M 122304556789101112 - +

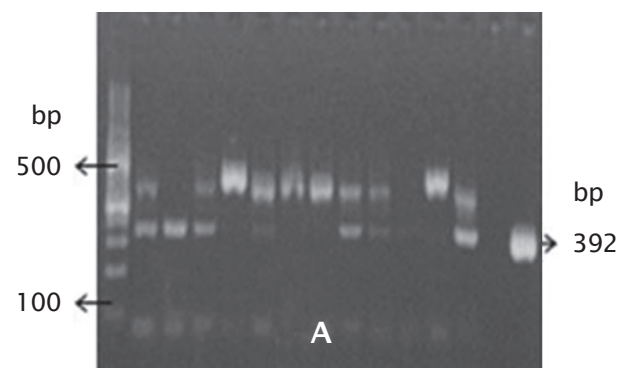

$12344567891011 M 1213141516171819+$ +

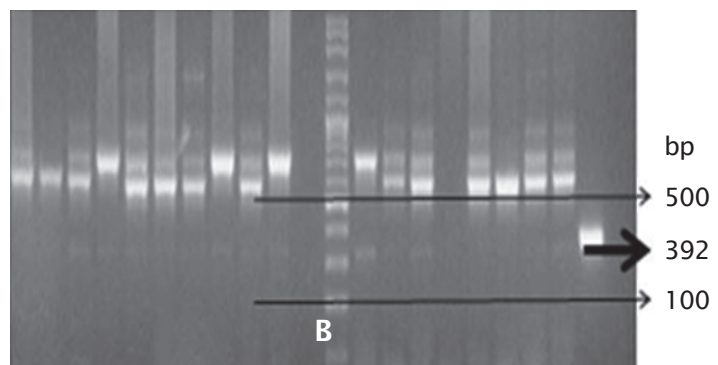

Gambar 1. Deteksi gen PhGH pada gonad dengan menggunakan metode PCR (A. Telur; nomor 1-12 = sel telur, dan (B. Sperma) nomor 1-19= sperma pada ikan lele F-1. M adalah marker DNA (100-3.000 bp) (Vivantis). Tanda (+) adalah kontrol positif (pCcBA-PhGH). Tanda (-) adalah kontrol negatif. Ukuran fragmen gen PhGH 392 bp

Figure 1. Detection of PhGH gene in gonads using PCR method. (A. Eggs) lane 1-12=eggs, and (B. Sperm) lane 1-19 = sperm of African catfish F-1. M indicates a DNA marker (1003,000 bp) (Vivantis). (+) positive control (pCCBA-PhCH). (-) negative control. The expected size of the amplified fragment of $\mathrm{PhGH}$ gene is $392 \mathrm{bp}$ 
Tabel 1. Persentase induk F-1 yang membawa gen $\mathrm{PhCH}$ pada sirip ekor dan gonad Table 1. Percentage of founder F-1 that carries the PhGH gene in caudal fins and gonads

\begin{tabular}{lcc}
\hline $\begin{array}{c}\text { Transgenik F-1 } \\
\text { F-1 Transgenic }\end{array}$ & $\begin{array}{c}\text { Persentase induk F-1 yang } \\
\text { membawa transgen di sirip ekor } \\
\text { Percentage of F-1 broodstock } \\
\text { carried PhGH gene in caudal fin }\end{array}$ & $\begin{array}{c}\text { Persentase induk F-1 yang } \\
\text { membawa transgen di gonad } \\
\text { Percentage of F-1 broodstock } \\
\text { carried PhGH gene in gonads }\end{array}$ \\
\hline Betina (Female) & $37.14 \%(65 / 175)$ & $27.69 \%(18 / 65)$ \\
Jantan (Male) & $82.00 \%(41 / 50)$ & $46.34 \%(19 / 41)$ \\
\hline
\end{tabular}
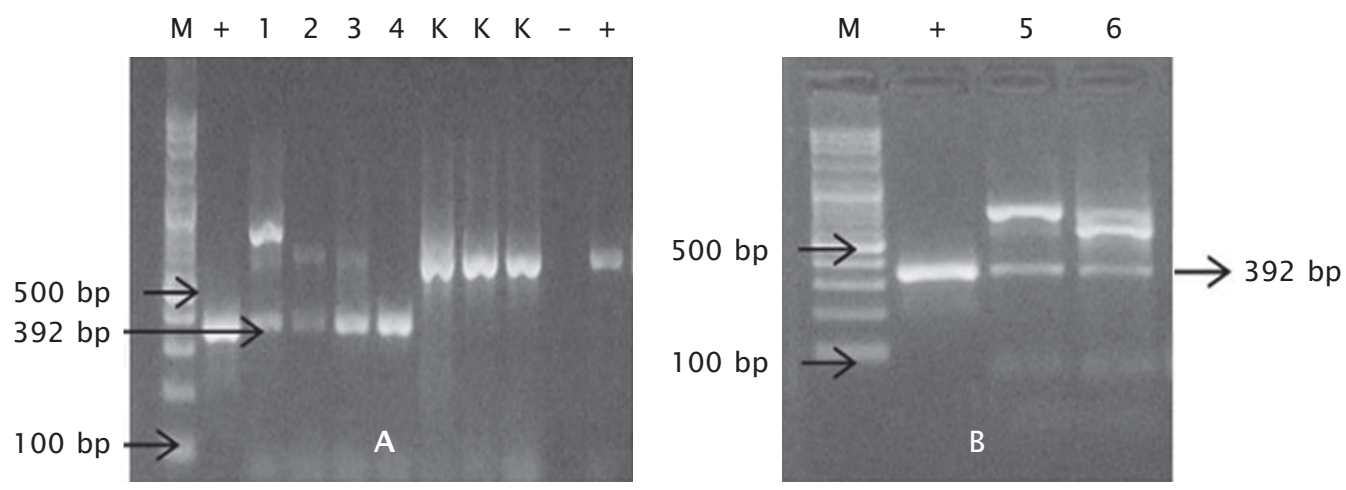

Gambar 2. Deteksi gen PhGH pada larva ikan lele F-2 dengan menggunakan metode PCR (A dan B); nomor 1-6 = sampel larva ikan lele F-2; K = kontrol (larva non-transgenik); M adalah marker DNA (100-3.000 bp) (Vivantis); tanda (+) adalah kontrol positif (pCcBA-PhGH); tanda (-) adalah kontrol negatif; ukuran fragmen gen PhGH 392 bp

Figure 2. Detection of PhGH gene in larvae of F-2 African catfish using PCR method (A and B); lane 1-6 = larvae of African catfish F-2; $K=$ control (non-transgenic larvae); $M$ indicates a DNA marker (100-3,000 bp) (Vivantis); (+) positive control (pCcBA-PhGH); (-) negative control; the amplified fragment of PhGH gene is $392 \mathrm{bp}$

Transmisi transgen pada ikan lele dari F-1 ke F-2 dari enam pasang induk berkisar $8,11 \%-50 \%$ dengan rata-rata transmisi transgen adalah 18,85\% (Tabel 2). Transmisi transgen tertinggi ditemukan pada persilangan antara ikan lele transgenik jantan nomor 5 dengan ikan lele transgenik betina nomor 2 dengan transmisi transgen sebesar 50\%. Menurut Chen et al. (1993), melaporkan bahwa transmisi transgen tertinggi pada F-2 hasil persilangan sesama induk F-1 transgenik sebesar $31 \%$ dan transmisi terendah sebesar $21 \%$, sedangkan transmisi transgen tertinggi pada $\mathrm{F}-2$ hasil persilangan antara induk F-1 transgenik dengan non-transgenik adalah sebesar $100 \%$ dan terendah sebesar 0\%. Hsiao et al. (2001) menyatakan bahwa transmisi transgen tertinggi pada ikan zebra F-2 hasil persilangan induk F-1 transgenik dengan non- transgenik adalah sebesar $59 \%$, sedangkan transmisi transgen terendah pada penelitian ini yaitu sebesar $8,11 \%$. Menurut Tewari et al. (1992), menyatakan bahwa transgen dapat terintegrasi pada satu atau beberapa lokasi di kromosom, hal ini yang menyebabkan transmisi pada beberapa ikan transgenik bervariasi. Shears et al. (1991) menyatakan bahwa jika transmisi transgen pada generasi F-2 yang dihasilkan dari persilangan sesama ikan transgenik F-1 mengikuti frekuensi Mendelian, ini mengindikasikan DNA terintegrasi stabil pada genom inang.

Transmisi transgen pada ikan lele dari F-1 ke F-2 hampir sama jika dibandingkan dengan transmisi transgen pada ikan lele F-0 ke F-1. Transmisi transgen dari F-0 ke F-1 berkisar 8\%$48 \%$ dengan rata-rata transmisi sebesar $38,22 \%$ dengan total sampel yang dicek adalah se- 
Tabel 2. Transmisi transgen pada populasi ikan lele Afrika transgenik F-2

Table 2. Transgene transmission in the F-2 transgenic African catfish populations

\begin{tabular}{cccc}
\hline $\begin{array}{c}\text { Induk transgenik F-1 } \\
\text { F-1 Transgenic broodstock }\end{array}$ & $\begin{array}{c}\text { Jumlah individu } \\
\text { yang diperiksa } \\
\text { The number of } \\
\text { individuals } \\
\text { examined }\end{array}$ & $\begin{array}{c}\text { Jumlah individu } \\
\text { yang positif } \\
\text { membawa transgen } \\
\text { The number of } \\
\text { positive individuals } \\
\text { carrying the transgene }\end{array}$ & $\begin{array}{c}\text { Persentase } \\
\text { transmisi } \\
\text { transgen } \\
\text { Percentage of } \\
\text { transgene } \\
\text { transmission }\end{array}$ \\
\hline Jantan (Male) $18 \times$ Betina (Female) 1 & 24 & 10 & 41.67 \\
Jantan (Male) $11 \times$ Betina (Female) 1 & 5 & 2 & 40.00 \\
Jantan (Male) $5 \times$ Betina (Female) 2 & 6 & 3 & 50.00 \\
Jantan (Male) $9 \times$ Betina (Female) 2 & 33 & 3 & 9.09 \\
Jantan (Male) $8 \times$ Betina (Female) 3 & 17 & 2 & 11.76 \\
Jantan (Male) $10 \times$ Betina (Female) 3 & 37 & 3 & 8.11 \\
\hline Jumlah (Total) & 122 & 23 & 18.85 \\
\hline
\end{tabular}

banyak 225 ekor (belum dipublikasi). Hasil penelitian sebelumnya yang dilaporkan oleh Liang et al. (2000), bahwa transmisi transgen pada ikan zebra dari F-1 ke F-2 yang membawa plasmid pCMVL sebesar 12,0\%-47,6\%. Hasil yang berbeda dilaporkan oleh Rahman \& Maclean (1999), menyatakan bahwa ikan nila F-2 yang membawa gen hormon pertumbuhan yang dihasilkan dari perkawinan transgenik F-1 dengan non-transgenik menghasilkan rata-rata transmisi transgen sebesar $50 \%$. Figueiredo et al. (2007), melaporkan bahwa ikan zebra F-2 yang membawa gen hormon pertumbuhan yang merupakan hasil persilangan transgenik F-1 dengan non-transgenik juga menghasilkan transmisi transgen pada F-2 sebesar 50\%. Stuart et al. (1990), juga melaporkan bahwa transmisi transgen yang membawa plasmid pUSVCAT pada ikan zebra dari F-1 ke F-2 berkisar 48\%-56\%.

\section{Ekspresi Gen PhGH pada Larva Ikan Lele Generasi F-2}

Gen PhGH terekspresi pada larva ikan lele transgenik populasi F-2 dari enam induk transgenik $\mathrm{F}-1$ yang disilangkan, sedangkan pada ikan kontrol (non-transgenik) gen $\mathrm{PhGH}$ tidak teramplifikasi (Gambar 3). Hal ini menunjukkan bahwa gen $\mathrm{PhGH}$ dapat ditranskripsikan pada larva ikan transgenik F-2. Gen $P h G H$ yang terekspresi pada larva dipengaruhi oleh promotor $\beta$-aktin yang digunakan pada konstruksi plasmid pCCBA-PhGH. Moav et al. (1992) melaporkan bahwa promoter $\beta$-aktin ikan mas menunjukkan ekspresi yang kuat bila diaplikasikan pada ikan mas. Selanjutnya Hamada et al. (1998) juga melaporkan bahwa promotor $\beta$-aktin ikan medaka merupakan promoter yang aktif dan mampu mengontrol ekspresi gen GFP. Ekspresi transgen yang kuat ditemukan pada larva ikan nila transgenik F-2 yang berumur sepuluh hari setelah fertilasi dengan menggunakan promoter $\beta$-aktin ikan medaka (Farlora et al., 2009).

\section{Deteksi, Distribusi, dan Ekspresi Gen PhGH pada Berbagai Organ Ikan Lele Generasi F-2 dengan Menggunakan Metode Absolut qPCR}

Gen $\mathrm{PhGH}$ selain terekspresi pada larva, juga terekspresi pada organ pituitari, hati, ginjal, gonad, otot, otak, timus, jantung, limfa, lambung, usus, insang, kulit, dan sirip ekor pada satu ikan, namun gen $\mathrm{PhCH}$ pada tiga ikan lainnya hanya terekspresi pada beberapa organ saja (Gambar 4 dan Tabel 3). Penelitian yang telah dilaporkan oleh Farlora et al. (2009) menyatakan bahwa transgen (gen $\beta$-aktin/ EGFP) pada ikan nila transgenik F-2 terdistribusi dan terekspresi pada insang dan operkulum, sirip ekor, otot, insang, jantung, hati, testis, dan ovari, sedangkan Mori \& Devlin (1998) melaporkan bahwa transgen terekspresi pada organ pituitari, hati, ginjal, kulit, usus, lambung, insang, otot, limfa, dan pyloric caeca pada ikan coho salmon. Transgen terdeteksi dan terekspresi pada hati, insang, jantung, otak, otot, ginjal, limfa, usus, dan testis pada ikan nila 

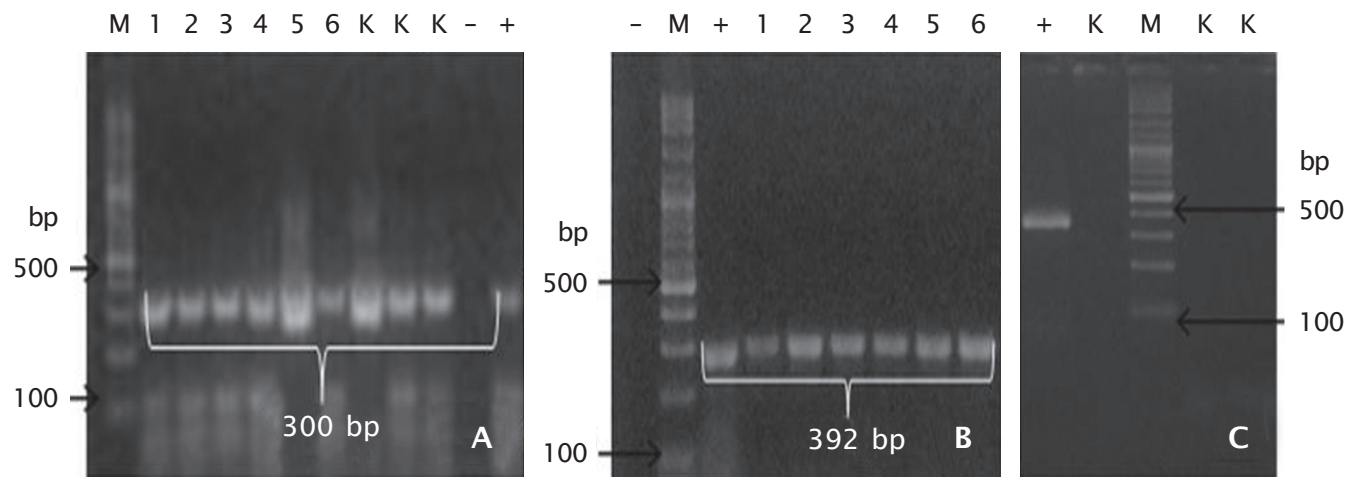

Gambar 3. Ekspresi gen PhGH pada larva ikan lele F-2 dengan menggunakan metode PCR (A. $\beta$ aktin sebagai kontrol internal ) nomor 1-6 = sampel $\beta$-aktin; (B. larva ikan transgenik F2) nomor 1-6 = sampel larva ikan lele transgenik F-2; (C. ekspresi larva ikan nontransgenik F-2); K adalah kontrol (non-transgenik); M adalah marker DNA (100-3.000 bp) (Vivantis); tanda (+) adalah kontrol positif (pCcBA-PhGH); tanda (-) adalah kontrol negatif; ukuran fragmen gen $P h G H 392$ bp; ukuran fragmen $\beta$-aktin 300 bp

Figure 3. PhGH gene expression in larvae of African catfish F-2 using PCR method (A. $\beta$-actin gene used as internal controls) lane 1-6 = $\beta$-actin gene samples; ( $B$. larvae of African catfish F-2) lane 1-6 = larvae samples of African catfish F-2; (C. Gene expression nontransgenic fish F-2); $K$ indicates controls; $M$ indicates a DNA marker (100-3,000 bp) (Vivantis); (+) positive control ( $p C c B A-P h C H)$; (-) negative control; the amplified fragment of PhGH gene is 392 bp; the amplified fragment fragment of $\beta$-actin gene is $300 \mathrm{bp}$

(Caelers et al., 2005; kobayashi et al., 2007), mata dan otak pada ikan salmon (Devlin et al., 2012). Penelitian selanjutnya yang dilaporkan oleh Hayat et al. (1991); Gross et al. (1992); Hackett (1993) melaporkan bahwa transgen terdeteksi tidak pada semua sel, jaringan, dan organ ikan transgenik.

Level ekspresi transgen tertinggi ditemukan pada organ hati berkisar $7,3 \pm 2,2 \mathrm{pg} / \mu \mathrm{g}$ cDNA - 9,2 $\pm 2,7 \mathrm{pg} / \mu \mathrm{g}$ cDNA dan terendah ditemukan pada ginjal berkisar 0,19 $\pm 0,01$ $\mathrm{pg} / \mu \mathrm{g}$ cDNA - 0,2 $\pm 0,03 \mathrm{pg} / \mu \mathrm{g}$ cDNA dan insang sebesar $0,2 \pm 0,01 \mathrm{pg} / \mu \mathrm{g}$ cDNA. Menurut Sarmasik (2003), menyatakan bahwa level ekspresi transgen selain dipengaruhi oleh promotor yang digunakan juga dipengaruhi oleh integrasi transgen dan situs integrasi transgen antara satu individu dengan individu lainnya. Hasil penelitian ini sama seperti yang dilaporkan oleh Caelers et al. (2005), di mana ekspresi gen hormon pertumbuhan $(\mathrm{sGH})$ tertinggi ditemukan pada hati sebesar $8,5 \mathrm{pg} / \mu \mathrm{g}$ RNA \pm 2,5 . Ekspresi gen hormon pertumbuhan yang tinggi di hati akan memengaruhi pertumbuhan pada ikan, baik secara langsung ataupun tidak langsung. Mekanisme secara langsung adalah ekspresi gen hormon pertumbuhan yang tinggi pada hati akan merangsang pembentukan hormon pertumbuhan pada ikan tanpa perantara IGF-I di dalam hati, sedangkan mekanisme tidak langsung adalah ekspresi gen hormon pertumbuhan merangsang pembentukan hormon pertumbuhan yang dimediasi oleh IGF-I dalam hati ikan (Ohlsson et al., 2009).

\section{KESIMPULAN}

Gen PhGH terdeteksi pada telur induk betina F-1 transgenik sebesar $(27,69 \%)$ dan $(46,34 \%)$ pada sperma induk jantan. Transgen dapat terdeteksi pada larva dan sirip ekor ikan lele transgenik F-2 dengan persentase transmisinya adalah $8,11 \%-50 \%$ dengan rata-rata transmisi transgen sebesar $18,85 \%$. Deteksi dan distribusi transgen ditemukan pada larva dan organ pituitari, hati, ginjal, gonad, otot, otak, timus, jantung, limfa, lambung, usus, insang, kulit, dan sirip ekor. Level ekspresi transgen tertinggi ditemukan pada hati sebesar $7,3 \pm 2,2 \mathrm{pg} / \mu \mathrm{g}$ cDNA $-9,2 \pm 2,7 \mathrm{pg} / \mu \mathrm{g}$ cDNA, sedangkan ekspresi terendah ditemukan pada ginjal berkisar $0,19 \pm 0,01 \mathrm{pg} / \mu \mathrm{g}$ cDNA - 0,2 $\pm 0,03 \mathrm{pg} / \mu \mathrm{g}$ cDNA dan insang sebesar $0,2 \pm 0,01 \mathrm{pg} / \mu \mathrm{g}$ cDNA. 

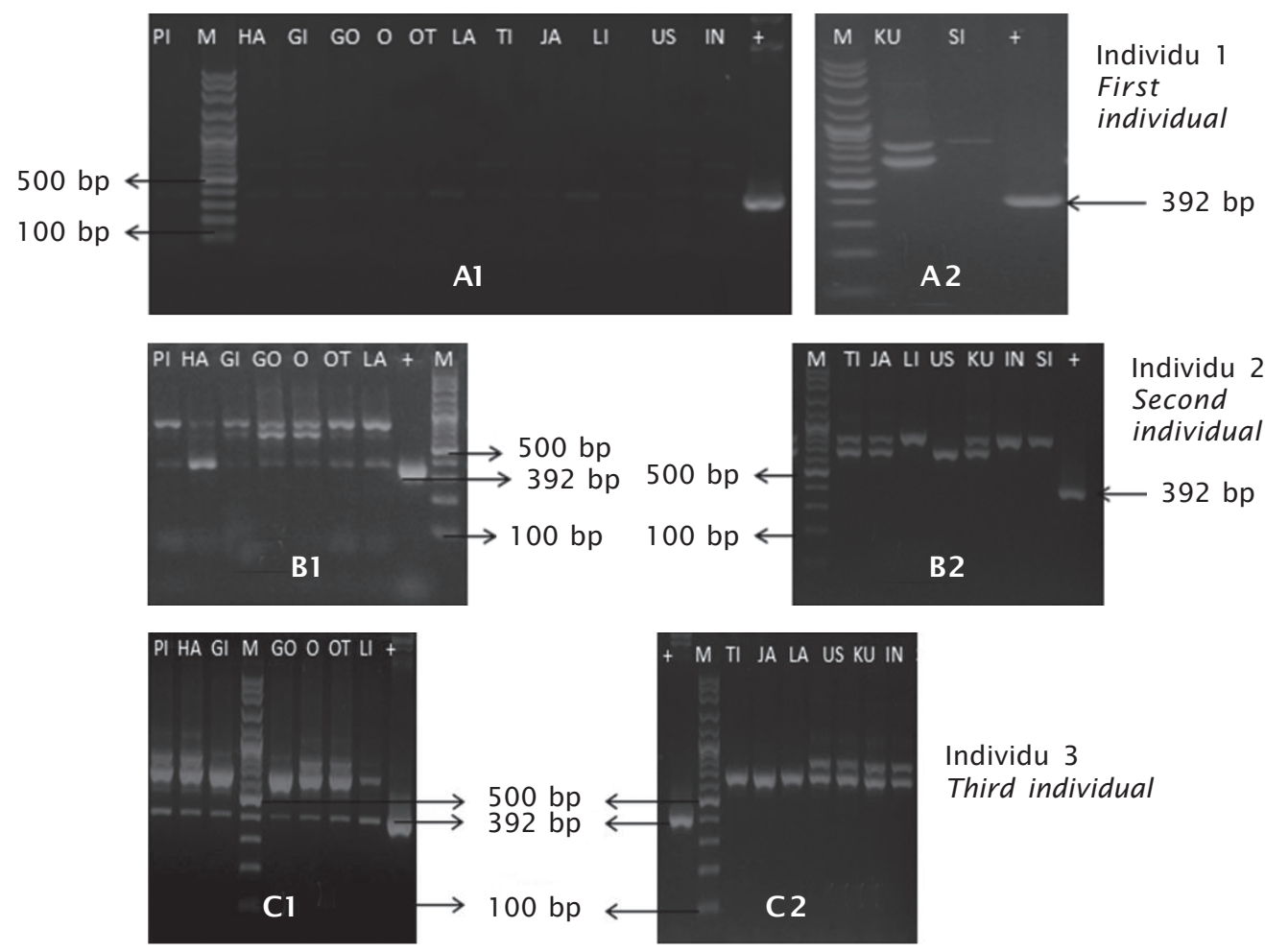

Individu 3

Third individual

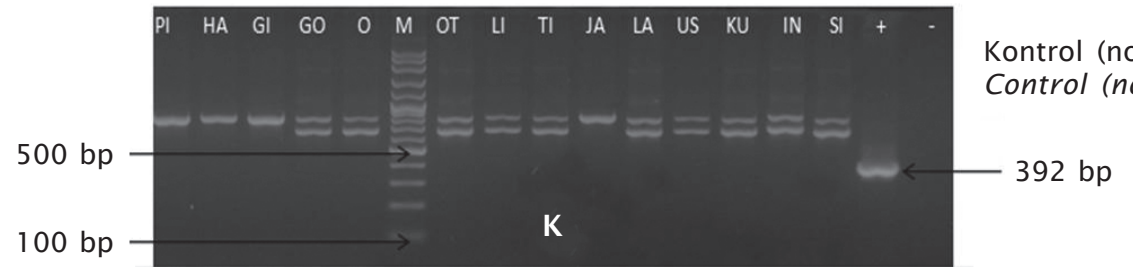

Gambar 4. Deteksi gen $\mathrm{PhGH}$ pada berbagai organ ikan lele F-2 dengan menggunakan metode PCR; A1. Organ individu 1 yang terdeteksi gen $P h G H ; A 2$. Organ individu 1 yang tidak terdeteksi gen $\mathrm{PhCH}$; B1. Organ individu 2 yang terdeteksi gen $\mathrm{PhCH}$; B2. Organ individu 2 yang tidak terdeteksi gen $\mathrm{PhCH} ; \mathrm{Cl}$. Organ individu 3 yang terdeteksi gen $\mathrm{PhGH}$; C2. Organ individu 3 yang tidak terdeteksi gen $\mathrm{PhGH}$; D. Organ individu 4 yang terdeteksi gen $\mathrm{PhGH}$; $\mathrm{K}$ adalah kontrol (non-transgenik); $\mathrm{PI}=$ pituitari; $\mathrm{HA}=$ hati; $\mathrm{Gl}=$ ginjal; $\mathrm{CO}=$ gonad; $\mathrm{O}=$ otak; $\mathrm{OT}=$ otot; $\mathrm{LI}=\operatorname{limfa} ; \mathrm{TI}=$ timus; $\mathrm{JA}=$ jantung; $\mathrm{LA}=$ lambung; US = usus; $\mathrm{KU}=$ kulit; IN = insang; $\mathrm{SI}$ =sirip ekor; $\mathrm{M}$ adalah marker DNA (100-3.000 bp) (Vivantis); tanda (+) adalah kontrol positif (pCcBA-PhGH); tanda (-) adalah kontrol negatif; ukuran fragmen gen $\mathrm{PhGH} 392 \mathrm{bp}$

Figure 4. Detection PhGH gene in various organs in F-2 transgenic African catfish using PCR method; A1. First individual organ that was detected PhGH gene; A2. First individual organ that was not detected PhGH gene; B1. Second individual organ that was detected PhGH gene; B2. Second individual organ that was not detected PhGH gene; C1. Third individual organ that was detected PhGH gen; C2. Third individual organ that was not detected PhGH gene; $K$ indicates controls (non-transgenic); $P I=$ pituitary; $H A$ = liver; $G I$ = kidney; $G O=$ gonad; $O=$ brain; $O T=$ muscle; $L I=$ spleen; $T I=$ thymus; $J A$ = heart; $L A=$ stomach; US = intestine; $K U=$ skin; IN = gill; $S I=$ caudal fin. $M$ indicates a DNA marker (100-3,000 bp) (Vivantis); (+) positive control (pCcBA-PhCH); (-) negative control; the expected size of the amplified fragment of $\mathrm{PhGH}$ gene is $392 \mathrm{bp}$ 


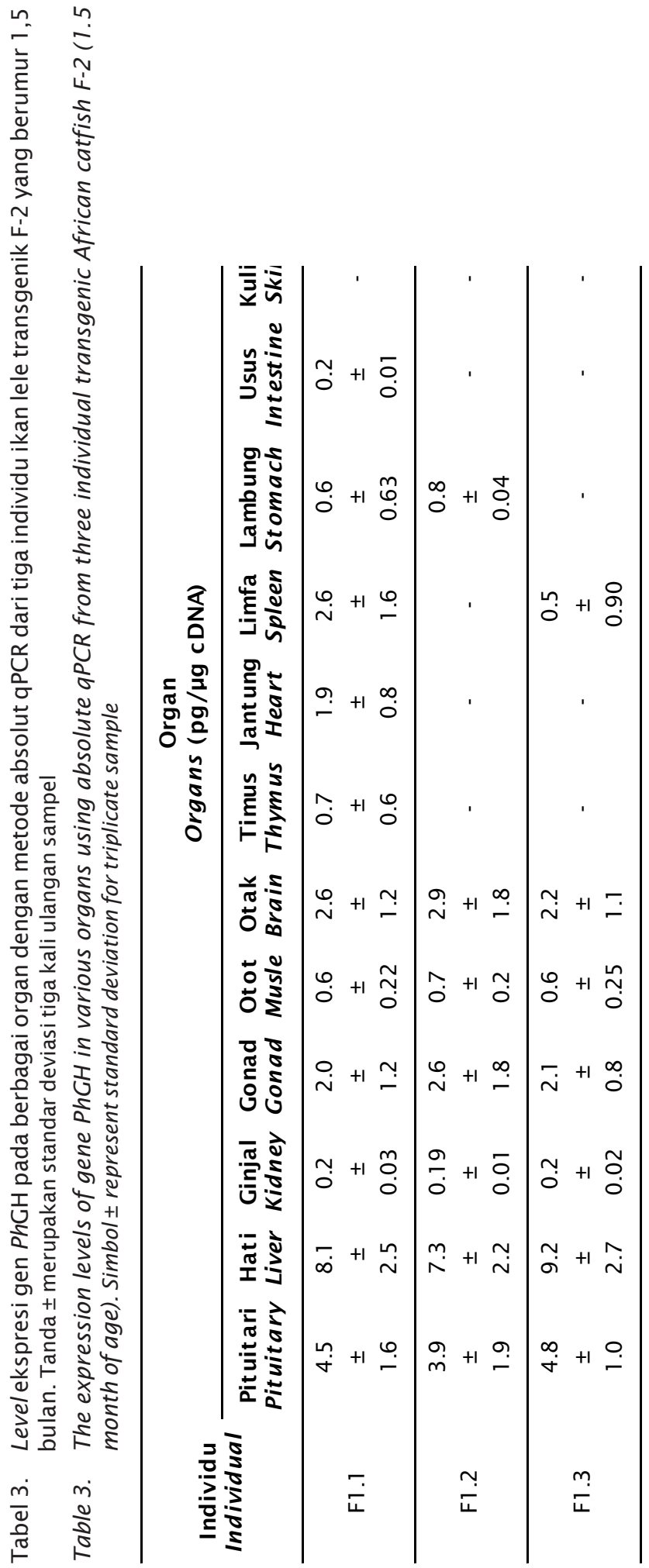




\section{DAFTAR ACUAN}

Chen, T.T., Lin, C.M., Lu, J.K., Shamblott, M., \& Kight, K. 1993. Transgenic fish: A new technology for fish production. In Science for the Food Industry of the $21^{\text {st }}$ century, biotechnology, supercritical fluids, membranes and other advanced technologies for low calorie, healthy food alternatives. Yalpani, M. (Ed.), Chap., 10: 145-15.

Caelers, A., Maclean, N., Hwang, G., Eppler, E., \& Reinecke, M. 2005. Expression of endogenous and exogenous growth hormone (GH) messenger mRNA in a $\mathrm{H}$-transgenic tilapia (Oreochromis niloticus). Transgenic. Res., 14(1): 95-104.

Cole, A.M., Darouiche, R.O., Legarda, D., Connell, N., \& Diamond, G. 2000. Characterization of a fish antimicrobial peptide: gene expression, subcellular localization, and spectrum of activity. Antimicrobial Agents and Chemotherapy, 44: 2,039-2,045.

Cressey, D. 2009. Future fish. Nature, 458: 398400.

Devlin, R.H., Yesaki, T.Y., Biagy, C.A., Donaldson, E.M., Swanson, P., \& Chan, W.K. 1994. Extraordinary salmon growth. Nature, 371 : 209-210.

Devlin, R.H., Yesaki, T.Y., Donaldson, E.M., \& Hew, C.L. 1995. Transmission and phenotypic effects of an antifreeze/GH gene construct in coho salmon (Oncorhynchus kisutch). Aquaculture, 137: 161-169.

Devlin, R.H., Biagi, C.A., \& Yesaki, T.Y. 2004. Growth, viability and genetic characteristics of $\mathrm{GH}$ transgenic coho salmon strains. Aquaculture, 236: 607-632.

Dewi, R.R.S.P.S. 2010 . Studi over-ekspresi gen penyandi hormon pertumbuhan melalui elektroforesis sperma untuk membuat ikan patin siam transgenik cepat tumbuh. Disertasi. Institut Pertanian Bogor. Bogor, $75 \mathrm{hlm}$.

Dewi, R.R.S.P.S., Marnis, H., Suprapto, R., \& Rizwan, S.N. 2013. Produksi ikan lele transgenik tumbuh cepat F-O menggunakan metode transgenesis. Jurnal Riset Akuakultur, 8(2): 173-180.

Douglas, S.E., Gallant, J.W., Gong, Z., \& Hew, C. 2001. Cloning and developmental expression of a family of pleurocidin-like antimicrobial peptides from winter flounder, Pleuronectes americanus (Walbaum). Developmental and Comparative Immunology, 25: 137-147.
Du, S.J., Gong, Z., Fletcher, G.L., Shears, M.A., King, M.J., Idler, D.R., \& Hew, C.L. 1992. Growth enhancement in transgenic Atlantic salmon by the use of an "all fish" chimeric growth hormone gene construct. Biol. Tech., 10: 176-180.

Farlora, R., Kobayashi, S., França, L.R., Batlouni, S.R., Lacerda, S.M.S.N., \& Yoshizaki, G. 2009. Expression of GFP in transgenic tilapia under the control of the medaka $\beta$-actin promoter: establishment of a model system for germ cell transplantation. Anim. Reprod., 6(3): 450-459.

Fletcher, G.L., Hobbs, R.S., Evans, R.P., Shears, M.A., Hahn, A.L., \& Hew, C.L. 2011 . Lysozyme transgenic Atlantic salmon (Salmo salar L.). Aquaculture Research, 42: 427-440.

Figueiredo, M.A., Lanes, C.F.C., \& Almaida, D.V. 2007. Improving the production of transgenic fish germlines: In vivo evaluation of mosaicism in zebrafish (Danio rerio) using a green fluorescent protein (GFP) and growth hormone cDNA transgene co-injection strategy. Genetics and Molecular Biology, 30(1): 31-36.

Guan, B., Ma, H., Wang, Y., Hu, Y., Lin, Z., Zhu, Z., \& Hu, W. 2011 . Vitreoscilla hemoglobin (VHb) over expression increases hypoxia tolerance in zebrafish (Danio rerio). Marine Biotechnology, 13: 336-364.

Gross, M.L., Schneider, J.F., Moav, N., Moav, B., Alvarez, C., Myster, S.H., Liu, Z., Hallerman, E.M., Hackett, P.B., Guise, K.S., Faras, A.J., \& Kapuscinski, A.R. 1992. Molecular analysis and growth evaluation of northern pike (Esox lucius) microinjected with growth hormone genes. Aquaculture, 103: 253273.

Hackett, P.B. 1993. The molecular biology of transgenic fish. In Hochachka, P.W. \& Mommsen, T.P. (Eds.), Biochemistry and Molecular Biology of Fishes, Molecular Biology Frontiers. Elsevier. Amsterdam, 2: 207240.

Hallerman, E.M., McLean, E., \& Fleming, I.A. 2007. Effects of growth hormone transgenes on the behavior and welfare of aquacultured fishes: a review identifying research needs. Applied Animal Behaviour Science, 104: 265-294.

Hamada, K., Tamaki, K., Sasado, T., Watai, Y., Kani, S., Wakamatsu, Y., Ozato, K., Kinoshita, M., Kohno, R., Takagi, S., \& Kimura, M. 1998. Usefulness of the medaka $\beta$-actin promoter investigated using a mutant GFP reporter 
gene in transgenic medaka (Oryzias latipes). Mol. Mar. Biol. Biotechnol., 7: 173180.

Hayat, M., Joyce, C.P., Townes, T.M., Chen, T.T., Powers, D.A., \& Dunham, R.A. 1991. Survival and integration rate of channel catfish and common carp embryos microinjected at various developmental stages. Aquaculture, 99: 249-255.

Hew, C., Poon, R., Xiong, F., Gauthier, S., Shears, M., King, M., Davies, P., \& Fletcher, G. 1999. Liver-specific and seasonal expression of transgenic Atlantic salmon harboring the winter flounder antifreeze protein gene. Transgenic Research, 8: 405-414.

Hinit, Y. \& Moav, B. 1999. Growth performance studies in transgenic Cyprinus carpio. Aquaculture, 173: 285-296.

Hu, W. \& Zhu, Z.Y. 2010. Integration mechanisms of transgenes and population fitness of GH transgenic fish. Science China. Life Sciences, 53: 401-408.

Hsiao, C.D., Hsieh, F.J., \& Tsai, H.J. 2001. Enhanced expression and stable transmission of transgenes flanked by inverted terminal repeats from adeno-associated virus in zebrafish. Developmental Dynamic, 220: 323-336.

Kobayashi, S.I., Alimuddin, Morita, T., Endo, M., Takeuchi, T., \& Yoshizaki, G. 2007. Transgenic nile tilapia (Oreochromis niloticus) over expressing growth hormone show reduced ammonia excretion. Aquaculture, 270: 427-435.

Krasnov, A., Pitkanen, T.I., \& Molsa, H. 1999. Gene transfer for targeted modification of salmonid fish metabolism. Genetic Analysis: Biomolecular Engineering E., 15: 115 119.

Liang, M.R., Alestrom, P., \& Collas, P. 2000. Glowing zebrafish: integration, transmission, and expression of a single luciferase transgene promoted by noncovalent DNAnuclear transport peptide complexes. Mol. Reprod. Dev., 55: 8-13.

Lu, J.K., Fu, B.H., Wu, J.L., \& Chen T.T. 2002. Production of transgenic silver seabream (Sparus sarba) by different gene transfer methods. DOI: 10.1007/s10126-002-0027-8. Mar. Biotechnol., 4: 328-337.

Mao, W.F., Wang, Y.P., Wang, W.B., Bo, W., Feng, J.X., \& Zhu, Z.Y. 2004. Enhanced resistance to Aeromonas hydrophila infection and enhanced phagocytic activities in human lactoferrin-transgenic grass carp (Cteno- pharyngodon idellus). Aquaculture, 242: 93 103.

Martinez, R., Arenal, A., Estrada, M.P., Herrera, F., Huerta, V., Vazquez, J., Sanchez, T., \& de la Fuente, J. 1999. Mendelian transmission, transgene dosage and growth phenotype in transgenic tilapia (Oreochromis hornorum) showing ectopic expression of homologous growth hormone. Aquaculture, 173: 271-283.

Martinez, R., Estrada, M.P., Berlanga, J., Guillen, I., Hernandez, O., Cabrera, E., Pimentel, R., Morales, R., Herrera, F., Morales, A., Pina, T.C., Abad, Z., Sanchez, V., Melamed, P., Lleonart, R., \& delaFuente, J. 1996. Growth enhancement in transgenic tilapia by ectopic expression of tilapia growth hormone. Molecular Marine Biology and Biotechnology, 5: 62-70.

Moav, B., Liu, Z., Groll, Y., \& Hacket, P.B. 1992. Selection of promoters for transgenic fish. Mol. Mar. Biol. Biotechnol., 1: 338-345.

Mori, T. \& Devlin, R.H. 1999. Transgene and host growth hormone gene expression in pituitary and nonpituitary tissues of normal and growth hormone transgenic salmon. Molecular and Cellular Endocrinology, 149: 129-139.

Nam, Y.K., Noh, J.K., Cho, Y.S., Cho, H.J., Cho, K.N., Kim, C.G., \& Kim, D.S. 2001. Dramatically accelerated growth and extraordinary gigantism of transgenic mud loach (Misgurnus mizolepis). Transgenic Research, 10: 353-362.

Ohlsson, C., Mohan, S., Sjögren, K., Tivesten, A., Isgaard, J., Isaksson, O., Jansson, J.O., \& Svensson, J. 2009. The role of liver-derived insulin-like growth factor-I. doi: 10.1210/ er.2009-0010. Endocr. Rev., 30(5): 494-535.

Rahman, M.A. \& Maclean, N. 1999. Growth performance of transgenic tilapia containing an exogenous piscine growth hormone gene. Aquaculture, 173: 333-346.

Rahman, M.A., Mak, R., Ayad, H., Smith, A., \& Maclean, N. 1998. Expression of a novel piscine growth hormone gene results in growth enhancement in transgenic tilapia (Oreochromis niloticus). Transgenic Research, 7: 357-369.

Rahman, M.A., Ronyai, A., Engidaw, B.Z., Jauncey, K., Hwang, G., Smith, A., Roderick, E., Penman, D., Varadi, L., \& Maclean, N. 2001. Growth performance of transgenic tilapia containing an exogenous piscine growth hormone gene. Journal of Fish Biol- 
ogy, 59: 62-78.

Sarmasik, A. 2003. Application of gene transfer technology for genetic improvement of fish. Turki Journal of Zoology, 27: 1-6.

Shears, M.A., Fletcher, G.L., Hew, C.L., Gauthier, S., \& Davies, P.L. 1991. Transfer, expression, and stable inheritance of antifreeze protein genes in Atlantic salmon (Salmosalar). Molecular Marine Biology and Biotechnology, 1: 58-63.

Stevens, E.D. \& Devlin, R.H. 2005. Gut size in $\mathrm{GH}$-transgenic coho salmon is enhanced by both the $\mathrm{GH}$-transgene and increased food intake. Journal of Fish Biology, 66: 1,633-1,648.

Stuart, G.W., McMurray, J.V., \& Westerfield, M. 1988. Replication, integration and stable germ-line transmission of foreign sequences injected into early zebrafish embryos. Development, 103: 403-412.

Stuart, G.W., Vielkind, J.R, McMurray, J.V., \& Westerfield, M. 1990. Stable lines of transgenic zebrafish exhibit reproducible patterns of transgene expression. Development, 109: 577-584.

Tewari, R., Michard-Vanhée, C., Perrot, E., \& Chourrout, D. 1992. Mendelian transmis- sion, structure and expression of transgenes following their injection into the cytoplasm of trout eggs. Transgenic Research, 1:250-260.

Wang, R., Zhang, P., Gong, Z., \& Hew, C.L. 1995. Expression of the antifreeze protein gene in transgenic goldfish (Carassius auratus) and its implication in cold adaptation. Molecular Marine Biology and Biotechnology, 4: 20-26.

Wang, Y., Hu, W., Wu, G., Sun, Y., Chen, S., Zhang, F., Zhu, Z., Feng, J., \& Zhang, X. 2001. Genetic analysis of 'all-fish' growth hormone gene transferred carp (Cyprinus carpio L.) and its F1 generation. Chinese Science Bulletin, 46: 1,174-1,177.

Zhong, J.Y., Wang, Y.P., \& Zhu, Z.Y. 2002. Introduction of the human lactoferrin gene into grass carp (Ctenopharyngodon idellus) to increase resistance against $\mathrm{GCH}$ virus. Aquaculture, 214: 93-101.

Zhu, Z., Li, G., He, L., \& Chen, S. 1985. Novel gene transfer into the fertilized eggs of goldfish (Carassius auratus L. 1758). J. of Applied Ichthyology, 1: 31-34. 